\title{
Anaphoric resources in expository texts produced by children: The impact of a didactic sequence
}

\section{Recursos anafóricos en textos declarativos producidos por niños: el impacto de una secuencia didáctica}

\author{
Verónica Sánchez \\ FAPSE- Université de Genève \\ vsanchezabchi@yahoo.com.ar
}

María Dolores Plana

National Council of Scientific and Technical Research (CONICET)- CIIPME

doloresplana@gmail.com

María Elena Benítez

National Council of Scientific and

Technical Research (CONICET)-CIIPME maria_ebenitez@yahoo.com.ar

Received 01-Jun-2013/Accepted 23-Oct-2013

\begin{abstract}
This paper aims to explore the incidence of didactic strategies on the usage of anaphoric resources, in written expository texts, produced by Spanish speaking children, from Córdoba, Argentina. In order to identify and analyze the anaphoric resources used by children, we designed and implemented a sequence of didactic activities, based on gender textual characteristics. The genre to teach was the "encyclopedia entry". We analyzed the children production obstacles and difficulties and compared the productions before and after the didactic intervention, in order to assess the impact of teaching in the development of the cohesion devices. Eighty Spanish speaking children, of 3rd grade who attended two schools from Córdoba, Argentina, participated in this study. The results showed consistent changes after the didactic intervention that mainly consisted in an increase of the diversity of resources and the adequacy score in final productions; a higher presence of lexical resources, a higher precision and a decrease of ambiguous ellipsis.
\end{abstract}

Key Words: anaphoric resources, textual gender, expository texts, didactic intervention, written production.

\section{Resumen}

Este trabajo se propone explorar la incidencia de las estrategias didácticas en el uso de recursos anafóricos, en textos escritos expositivos, producidos por niños hablantes de español de la provincial de Córdoba, Argentina. Para poder identificar y analizar los recursos anafóricos utilizados por los niños, diseñamos y pusimos en práctica una secuencia de actividades didácticas, basada en las características del género textual. El género que se trató fue -el artículo enciclopédico-. A fin de poder evaluar el impacto en el desarrollo de los mecanismos de cohesión, analizamos los obstáculos de producción y las dificultades de los niños y comparamos los textos producidos antes y después de la intervención didáctica. Participaron del estudio 80 niños hispanohablantes, de 3er grado, que asistían a dos escuelas de Córdoba, Argentina. Los resultados mostraron cambios consistentes después de la intervención, que consistieron principalmente en un incremento de la diversidad de recursos y en el puntaje de adecuación en las producciones finales, así como en una presencia mayor de recursos léxicos, una mayor precisión y una disminución de las ellipsis ambiguas.

Palabras clave: recursos anafóricos, género textual, textos expositivos, intervención didáctica, producciones escritas. 
Anaphoric resources in expository texts produced by children

\begin{abstract}
Résumé
Ce travail vise à explorer l'influence des stratégies didactiques sur l'emploi des ressources anaphoriques, dans des textes expositifs écrits par des enfants hispanophones de Córdoba, Argentine. Afin d'identifier et analyser les ressources anaphoriques employées par les enfants, nous avons développé et implémenté une séquence didactique d'activités, basée sur le concept de genre textuel et le développement de ses caractéristiques. Le genre textuel choisi a été "l'article encyclopédique". Nous avons analysé les difficultés de production des enfants, et nous avons comparé les textes avant et après l'implémentation de la séquence, l'objectif étant d'évaluer l'impact de l'enseignement sur le développement des mécanismes de cohésion. Quatre-vingts enfants hispanophones, de 3ème année de primaire ont participé de la recherche. Les résultats montrent des transformations importantes dans la performance des élèves, après l'implémentation de la séquence didactique. Ces changements comportent un accroissement du score d'adéquation dans les productions finales, une plus grande diversité des ressources, une présence plus élevée de ressources lexicales, un emploi plus précis et une basse de l'emploi des ellipses ambiguës.
\end{abstract}

Mots clés: ressources anaphoriques, genre textuel, textes expositifs, intervention didactique, production écrite.

\title{
Introduction
}

This paper aims to explore whether specific didactic strategies affect children usage of anaphoric resources in written expository texts, produced by Spanish speaking children, from Córdoba, Argentina. We designed and put into practice a sequence of activities, based on gender textual characteristics, in a group of 80 3rd grade children in order to analyze lexical cohesion traces and anaphoric resources in expository texts. We also assessed the impact of educational intervention on children's written performance. The possibility to link a text cohesively depends on the development of cohesive mechanisms (Chafe, 1974; Chafe, 1976). In fact, the adequate usage of cohesive relationships ensures and enables surface text cohesion. Moreover, texts with suitable cohesion chains can be comprehended with minor effort than texts with weak ones. Cognitive perspectives explain this evidence by postulating that texts with conventional cohesion networks could demand less working memory resources. In this sense, it is important to improve teaching strategies for children to learn to display adequate cohesive relationships.

Among the cohesive resources, anaphoric expressions have a fundamental importance (see revision in Borzone E Silva, 2010). The anaphoric expressions can be defined as items that allow speakers to retrieve referents previously introduced, in order to increase accessibility to memory nodes linked to these concepts. The linkages which establish anaphoric cohesion include ellipsis, usage of pronouns and mechanisms of lexical cohesion. Lexical cohesion is achieved by the vocabulary and it involves repetitions, the use of synonyms and supraordinate or general word (see revision in Abadiano, 1995).

Even when very young children can use pronouns (Hernández, 1985) they have difficulties to use them appropriately in the chain of reference. In this sense, preschool children can use pronouns in their narratives to refer a name previously introduced. However, the relationship between the pronoun and the reference can be ambiguous (Shapiro $\&$ Hudson, 1997). Although the studies have obtained different results concerning the development of the referential system, some general acquisition patterns could be identified. Young children produce texts with relative simple anaphoric strategies. From 5 years old, a thematic subject strategy has been reported (Borzone E Granato, 1995). But a complete anaphoric strategy, that allows children to use pronouns in a flexible way, was not observed before 8 years (See revision Hudson E Shapiro, 1997).

In addition, the pattern of use of anaphoric resources can vary not only with the age of subjects, but also with the type of task and the textual genre (Schneuwly, 1988; Hickman, Kail \& Roland, 1995; Kail, Sánchez \& López, 1997; Jisa, 2000; De Weck; 1991; Cox, Shanahan \& Tinzman, 1991; Crowhurst, 
1987, among others) and the knowledge of this variation is acquired during development.

In Spanish, mainly the narrative anaphoric resources have been studied (for a revision, see Borzone \& Silva, 2010). Kail \& Sánchez and López (1997), who worked with narratives produced by children and adults, observed that the young children (5-9 years) performance could vary depending on the communicative situation. When children were aware that the listener knew the story, this knowledge had an incidence in the usage of referential expressions. The authors also identified some restrictions concerning the Spanish language: children should learn that pronouns are necessary -but not compulsory- in the agent position; mainly in linguistic context in which the verb is not sufficient to identify the subject. Aguilar (2003) observed that the fiction narratives produced by 6 years old children, with the support of images, included mostly a thematic subject strategy, whereas in texts produced by older children an anaphoric strategy was used: they used nominal phrases to change the reference and pronouns to keep the referential chain. Recently, Borzone and Silva (2010) studied the narratives produced by children and students between 5 and 16 years and observed that anaphoric expressions of youngest children presented the characteristics of the nominal strategy (Shapiro $\varepsilon$ Hudson, 1997). They also found that the children could use ellipsis in the subject position, which is the most frequent strategy to keep the reference chain in Spanish, due to the fact that it is a pro-drop language. Besides, the authors observed -in agreement with other researches (Karmiloff - Smith, 1980, 1986; Jisa, 1990; Shapiro \& Hudson, 1997) - that the mechanisms of references could vary depending on the demand of the task and the characteristics of the language.

On other side, as we pointed before, some linguistic characteristics can also vary with the genre. For instance, the usage of textual organizers is different in narratives and in argumentations (Schneuwly, 1988). Concerning the specific characteristics of the anaphoric system, in different works it have been studied the reference mechanisms according to genre
(Crowhurst, 1987; De Weck E Schneuwly, 1994; Cox E Tinzmann, 1991; Reilly, Zamora, \& Mc Givern, 2005). In this sense, differences between the production of expository and narrative texts, in relation with anaphoric resources, were identified (De Weck, 1991; Decool-Mercier and Ali, 2010; Hickmann E Roland, 1995; for French; Abadiano, 1995; Reilly, Zamora, \& Mc Givern, 2005, for English, among other). In English, for example, Reilly, et al. (2005), posits that expository texts include more impersonal or universal pronouns than narrative texts. Nevertheless, to date, little research has been specifically addressed the development of referential mechanisms of expository texts, written by Spanish speaking children.

Actually, the specific linguistic characteristics of a genre are part of the concept of genre itself. The textual genres represent the "crystallization" of the social representations implied in the interactions (Bajtin, 1993). The different discourse genres -oral and written- are considered a repertoire of communication ways that the speakers can use in their interactions. Each genre has specific grammatical features, vocabulary and stylistic characteristics. To learn the different genres of discourse, it is necessary, at the same time, to acquire their typical linguistic forms, such as specific connectors, specific vocabulary and specific anaphoric resources (Bronckart, 1996).

This concept is central in the frame of the sociodiscursive- interactionism (Bronckart, 1996) which considers the linguistic activity as social and contextualized and pays special attention to the role of language and discourse in the interactions. On the base of these principles, didactic tools which work with the characteristics and the values of genres were elaborated (Dolz, Noverraz, \& Schneuwly, 2001). A didactic sequence with a textual genre approach is an instrument that allows the selection and the organization of contents to teach, considering the different aspects of a specific genre. The sequence begins with an initial production, in order to identify the positive aspects - that means, the adequate use of the anaphoric mechanisms - and the problems of 
pupil's texts. The activities are organized in modules. The sequence implemented in this study had four modules, which allowed working on different aspects of the "encyclopedia entry". The four modules lead to a new text production, the "final production".

In our work, we elaborated a didactic sequence in order to guide the pupils to write encyclopedia entries for a class project. The genre "encyclopedia entry" is an expository text. The goal of the enunciator, who is supposed to be an expert in the domain, is to provide information for the interlocutors (Pasquier E Joaquim, 1990). In this type of texts, certain coherence mechanisms are the trace of the enunciator operations: select and reason. The first operation selects some characteristics of the object to the detriment of other that are eliminated. The second one imposes a particular organization on the selected information (Coltiert, 1986). In this sense, the different anaphoric resources, as the reformulation resources and the lexical substitution mechanisms, allow both operations. In fact, they help to select a noun that highlights some characteristics of the object, or they became a possibility to "condense" the information, in order to organize the progression of the topic.

In this study, we focus on the cohesion mechanisms used in the construction of the anaphoric chain, in expository texts written by 3rd grade pupils, in the frame of the implementation of a didactic sequence of genre. We aim to identify the mechanisms they employ and to compare the usage of the anaphoric resources before and after the didactic intervention. The children were not used to produce written texts and the interaction with the expository texts was scarce. In this sense, we analyze the children's productions in order to assess the incidence of teaching in the development of the cohesion devices.

\section{Methodology}

\section{Participants}

Eighty Spanish speaking children, of 3rd grade who attended two schools from Córdoba, Argentina, participated in this study. The students -49 girls and 31 boys- had an average age of $8.4(\mathrm{SD}=0.6$; extremes 7.6 and 9.7). The population attending these schools is constituted by children from middle and lower middle class families.

Initially the sample was larger, but some children were absent in one of two moments of production. Only those students who wrote both texts (initial and final production) were considered for the study.

\section{Procedure and materials}

The intervention program was designed considering two different types of participants: teachers and pupils.

For the teachers, a guide course was carried out. The guide course consisted of two sessions before the beginning of the experience, a weekly session during the implementation of the didactic sequence and a final session to assess the experience. In the preparation sessions, the main concepts were explained, the sequence activities plan was presented and discussed, on the base that the activities could be modified according to the children's initial productions. The weekly sessions aimed to assess the impact of the activities and to modify them if it was necessary. During the whole process, the importance of the teacher-pupils interactions was emphasized, in order to support the learning process.

For the pupils, a didactic sequence to write encyclopedia entries was designed. The application of the sequence was developed over 3 weeks, in sessions of 40 minutes. Before and after the sequence, children were asked to write an encyclopedia entry on a native animal. The instruction of the initial production (henceforth IP) was to write an encyclopedia article about a native animal, a text presenting their characteristics and customs. Previously, children had sought information to share it in the classroom, with the support of teachers. Later, they watched a documentary film about the animals which explained some of their characteristics, its geographical distribution, their hunting habits, customs and 
ecological status. At the time of production, the teacher told them they were going to write texts to publish on a virtual encyclopedia on the Internet, where everybody could read their texts. In this sense, the productions should be clear, accurate and complete.

During the implementation of the sequence, the children also looked for information about other animals. In the final production (henceforth FP), children had the opportunity to choose another animal which they had investigated about.

The didactic sequence included four modules:

1) Of the genre. In this module, the typical structure of an encyclopedia entry was introduced and explained. Activities to recognize their characteristics and identify the text among other kind of texts were promoted. Children were confronted to a diversity of encyclopedia entries, in order to discover their textual function and the typical communicative situation. In the oral interactions, teachers also pointed out the general linguistic aspects typical of this genre (verbal tenses, necessity to explicit the topic in order to avoid ambiguities, etc.)

2) Structure of the article. In this module, activities to recognize, manipulate and complete the structure of different texts were carried out. Special attention was addressed to the linguistic resources to link every "part" of the text. The activities fostered the identification of anaphoric resources that allow the cohesion between the different phrases of the texts.

3) Anaphoric resources. This module included activities to recognize mechanisms to maintain and ensure the anaphoric chain and activities to substitute the referent adequately. Lexical strategies, like the introduction of technical names or periphrasis to refer to the topic, and grammatical resources -that included the use of possessive pronouns- were taught in the module. The activities could be exercises to complete a text or to reformulate it. They could also consist in the correction of some of the IP.
4) Punctuation. Even when initially the punctuation was not part of the didactic sequence, the teachers observed that it was an aspect that should be treated in connection to the sequence. In this sense, a reflection over the importance of the punctuation was promoted. At the same time, specific activities were developed in order to improve the initial productions.

The proposals developed in the sequence could be both, individual or group activities. In any case, there was always a collective correction. The teacher oral interventions were constant in order to explain concepts or support children in the development of the activities.

\section{Analysis of empirical information}

Firstly, the length of the productions (calculated in quantity of words) and T-units were considered. For the analysis of anaphoric cohesion, two aspects were analyzed: First, the repertoire of lexical and grammatical mechanisms of cohesion, used to maintain co-reference. Secondly, we examined whether students were able to use adequately the mechanisms of cohesion to refer to the animal and to introduce new information about it. In order to gauge the level of adequacy, we considered the codification criteria of Schneider E Dubé (1997), adapted to Spanish:

A referential expression used to present a referent for the first time was considered adequate if a noun phrase with a definite article was used.

Expressions without article were coded as inappropriate.

Pronouns or ellipses, when present a referent for the first time, were coded as inappropriate.

The expressions to retrieve a referent previously introduced were considered adequate if they refer to the antecedent clearly.

To calculate the score of adequate reference for each text produced by a child, the number of appropriate referring expressions was divided by the 
total number of terms of reference included in the story written by the child.

\section{Results}

Overall, the final productions appear to be longer, more accurate and present a better organization of the information than the initial ones. In fact the mean length text -considering words amount- was increased in final productions (IP: $M=49.35 ; S D=28.5 ; F P$ : $M=59.64 ; S D=25.9$ ). The difference between both moments was significant $(t=-2,296$; fd 158, $p=.023)$.

The fact that the increment of the text's extension is moderate could be explained by the content selection. In the initial productions, some long texts didn't provide relevant information concerning the typical characteristics of the genre. Instead of that, these texts presented irrelevant information of the documentary film, like anecdotes that did not bring details about the animals. These contents disappeared completely in the final productions. In this sense, the didactic work on the genre characteristics allow us to suppose that the progress in length observed in final productions can be due to the fact that pupil include relevant contents and let out anecdotic information.

Concerning the mechanisms to keep the anaphoric chain, the number of anaphoric references raise from 622 in the IP to 657, in the FP. Likewise, the adequacy reference score was also increased (IP = $0.92 ; \mathrm{FP}=0.98$ ) with a significant difference between both moments of production $(\mathrm{t}=2.48 ; \mathrm{gl}=79$; sig. $=$ .015). The increment of the adequacy score means that children not only use more references resources, increment which could be expected considering the increment of length, but they use them actually in a more precise way, which suggest a better command of the strategy.

In fact, a difference in the distribution of the resources included was also noticed. In this regard, the descriptive statistics indicate that the sample exhibited differences in the repertoire of resources identified, in both moments of production. Table 1 presents the repertoire of categories in every moment. The number indicates the total of occurrences.

Table 1. Repertoire of Categories in Initial and Final Productions

\begin{tabular}{|l|r|r|r|r|}
\hline \multirow{2}{*}{ Categories } & \multicolumn{2}{|c|}{ Initial Production } & \multicolumn{2}{|c|}{$\begin{array}{c}\text { Final } \\
\text { Production }\end{array}$} \\
\cline { 2 - 5 } & $\mathbf{M}$ & SD & M & SD \\
\hline Ellipsis & 5.16 & 3.58 & 5.02 & 2.51 \\
\hline Defined Article + Noun & 1.60 & 1.30 & 1.78 & 0.90 \\
\hline Synonym & 0.07 & 0.26 & 0.04 & 0.19 \\
\hline Technical name & 0.12 & 0.40 & 0.18 & 0.47 \\
\hline Periphrasis & 0.00 & 0.00 & 0.23 & 0.52 \\
\hline Personal pronoun & 0.18 & 0.47 & 0.16 & 0.46 \\
\hline Possessive + noun & 0.26 & 0.68 & 0.74 & 0.91 \\
\hline Relative Pronoun & 0.26 & 0.47 & 0.50 & 0.2 \\
\hline
\end{tabular}

The most frequent resource in both moments was the ellipsis (Ø), as it was observed in previous studies conducted in Spanish (Borzone \& Silva, 2011). This may not be unexpected since Spanish is a pro-drop language. In some texts, ambiguous ellipsis -whose immediate referents were not clear-, was identified. However, the percentage of ambiguous ellipsis decreases considerably in the FP $(6,75 \%$ to $1,93 \%)$. The difference between both moments of assessment was significative $(t=10.581, \mathrm{fd} 79$, $\mathrm{p}=0.00)$.

On the other side, to introduce the animal that was described in the text but also to retrieve the referent, children used mostly the noun phrase, formed by the "article and the noun".

An overall view of both productions allows us to observe an increase of the diversity of the resources used in FP. The children begin to use periphrasis and technical names to reintroduce the referent. These strategies are illustrated in the next example:

El Puma es un animal mamífero vertebrado. $\varnothing$ Mide 2,05 sin contar la cola, $\varnothing$ no ruje sino $\varnothing$ ronronea. (...)Este felino se alimenta de carne (...). Este mamífero habita en toda América, en zonas boscosas y 
montañosas. $\varnothing$ Tiene visión nocturna, $\varnothing$ caza de noche y $\varnothing$ duerme de día.

[The Puma is a vertebrate mammal $\varnothing$ (it) measures 2.05, not counting the tail, $\varnothing$ (it) doesn't roar but $\varnothing$ (it) purrs (...). This feline eats meat (...). This mammal lives in the Americas, in wooded and mountainous regions. $\varnothing$ (it) has night vision, $\varnothing$ (it) hunts at night and $\varnothing$ (it) sleeps during the day.] FP, subject 3

Likewise, children use more technical names to present and describe the attributes of the animals and they introduce expressions with possessive adjectives. This can suggest a progress in accuracy, in the final production, as illustrated in example (2).

La ballena

La ballena es mamífero, acuático, del orden de los cetáceos.

Los ruidos que $\varnothing$ hacen se escuchan a $150 \mathrm{~km}, \varnothing$ puede llegar a vivir entre 50 y 90 años, su piel es lisa, No tiene extremidades sino una aleta dorsal y una cola, No tiene diente sino barbas este mamífero es vertebrado, $\varnothing$ mide 25 metros su respiración es pulmonar (Azul)

[The whale is [a] mammal, aquatic, of the order Cetecea. The noises $\varnothing$ (they) make can be heard $150 \mathrm{~km}$ away, $\varnothing$ ( it) can live between 50 and 90 years, its skin is smooth, but it doesn't have extremities, but a dorsal fin and a tail, $\varnothing$ ( It) doesn't have teeth but beards. This mammal is vertebrate; $\varnothing$ (it) measures 25 meters his respiration is pulmonary.] $\mathrm{FP}$, subject 30 .

On the other hand, in the FP other expressions -categorized as "periphrasis"- are introduced to refer the animal: "este animal" (this animal), "este habitante de la pampa" (this inhabitant of the Pampas). These expressions include hypernymies and reach a percentage of $2,65 \%$ of the total mechanisms identified in the FP. Even when its frequency is not elevated, the results show that the repertoire of expressions to reintroduce the referents has increased.
With regard to other mechanisms, the usage of technical names, as synonyms to replace the referent, was observed also. These words -like "Macho" (male), "mamífero" (mammals), etc, - did not present a high frequency of occurrence nor in the IP neither in the FP. Nevertheless, there is a difference in the distributions between both moments of production. Indeed, in the IP the words "male" and "female" are more frequent, maybe because the texts reproduce the information provided in the documentary film, without a selection or organization of contents. On the contrary, in the FP, children select more precise topics to organize the information of the texts and the planification proposed in the didactic sequence does not considerer difference between sexes. In this sense, it seems understandable that these words tend to disappear in the FP. On the other hand, technical nouns like "mammals" or "feline" -that refer to the animal classification- are incorporated in the FP. The specific selection of technical names in the FP suggests a higher awareness of the usage of these words as a referent substitute and a progress in the conceptualization.

The usage of synonyms is scarce in both moments of production, IP and FP. Anyway, in some case, finding the exact synonym for the name of the animal is not possible. The case of "león Americano" and "puma" is an exception. The occurrences observed refer to this animal. In a text, a child use the inadequate expression "águila de rapiña" (eagle of prey), combining the name of the animal with the hyperonym "ave de rapiña" (bird of prey). However, the essay shows the effort of the child to try to look for other substitutes for the referent, avoiding the repetitions.

Considering the usage of pronouns, this resource did not have a high frequency in the children texts. The figures in table I show even a decrease in FP's, in the usage of pronouns as subject. These findings, that confirm the results of other studies (see Borzone E Silva, 2010 for a revision), are not surprising, considering the tendency in Spanish to 
omit the subject, when a precision is not required. The percentage of usage of personal pronouns in object position is slightly higher ( $2.51 \% \mathrm{IP} ; 3.26 \% \mathrm{FP})$. The presence of relative pronouns and constructions of possessive + noun are relatively low.

\section{Discussion}

The two main goals of this paper were, first, to identify the anaphoric mechanisms used by children in expository productions and, second, to assess the incidence of a didactic sequence on the pupils performance.

Overall, we found consistent changes after the didactic intervention, and these essentially reflect a positive impact of teaching. The main changes consist in an increase of the diversity of resources and the adequacy score in final productions; a higher presence of lexical resources, a higher precision and a decrease of ambiguous ellipsis.

The increase and incorporation of lexical resources is in consonance with other works in which it was observed that lexical rather than grammatical cohesion predominates in expository texts (Stotsky, 1983; Abadiano, 1995). In fact, contrary to the observation that expository texts include an important use of impersonal pronouns, the texts analysed in this paper show results a little bit different (Reilly, et al., 2005). The reason could be the specifity of the genre: The encyclopedy entries written by children are centered on a particular topic -the animal- and that constraints the possibility of using universal pronouns, because the objective is to keep the attention on mechanisms that refer to the main subject, the animal. Considering that there is just one topic about which the information is presented, some specific strategies of narrative texts, as a thematic subject, can not be analysed.

In addition, the variety of anaphoric resources identified shows some differences with the studies that explored the mechanisms used in narratives produced by Spanish speakers of the same age (Borzone $\mathcal{E}$ Silva, 2010) and with works that analyzed expository texts without considering didactic intervention (Concha, Aravena, Coloma, \& Romero, 2010). These findings appear to support the fact that anaphoric mechanisms depend on the genre and that the domain of these mechanisms are linked to teaching.

In this sense, the incidence of the didactic sequence on having a good command of references mechanisms affects, at the same time, the control of the genre characteristics, because both are strongly linked. In fact, when the children improve the usage of reference resources, their control of the operations "select" and "reason" (Coltiert, 1986) impact on the organization of the text and on the selection of contents. The progress in the use of the other types of anaphoric resources seems to occur simultaneously with an improvement in the organization and development of the text.

Finally, the results presented in this work show that the dominance of a particulary complex skill, like the ussage of anaphoric resources in expository texts, can be quickly developed in the frame of an adecuate pedagogical intervention. In this sense, the possibility to teach the anaphoric strategies in relation with a particular genre allows an integral learning that can fully improve children writing needs.

\section{References}

Abadiano, H.. (1995). Cohesion strategies and genre in expository prose: an analysis of the writing of children of ethnolinguistic cultural groups. Pragmatics, 5 (3), 299-324.

Aguilar, C. (2003) Análisis de frecuencias de construcciones anafóricas en narraciones infantiles. Estudios de Lingüística Aplicada, (22), 33-43.

Bajtin, M. (1993). Estética de la Creación Verbal. México: Siglo XXI.

Borzone, A. M. \& Granato, L. (1995). Discurso narrativo: algunos aspectos del desempeño lingüístico en niños de diferente procedencia social. Lenguas Modernas, 22, 137-166.

Borzone, A. M., \& Silva, M. L. (2010). De las imágenes al texto: focalización y uso de recursos anafóricos 
en relatos de niños y jóvenes. Summa Psicologica, 7 (1), 105-120 .

Bronckart, J.-P. (1996). Activité langagière, textes et discours: pour un interactionisme socio-discursif. París: Delachaux \& Niestlé.

Chafe, W. (1976). Givenness, contrastiveness, defmiteness, subjects, topics, and point of view. En C. N. Li (Ed.), Subject and topic (pp. 25-55). New York: Academic Press,

Chafe, W. (1974). Language and consciousness. Language, 50, 111-133.

Coltiert, D. (1986). Approches du texte explicatif. Pratiques, (51), 3-22.

Concha, S., Aravena, S., Coloma, C., \& Romero, V. (2010). Escritura expositiva en tres niveles de escolaridad: coherencia y dominio de recursos lingüísticos. Literatura y Lingüísica, (21), 75-92.

Cox, B. S., \& Tinzmann, M. (1991). Children's knowledge of organization, cohesion and voice in written exposition. Research in the teaching of English, 25(2), 179-218.

Crowhurst, M. (1987). Cohesion argument and narration at three grade levels. Research in the teaching of English 21(2),185-201.

De Weck, G. (1991). La cohésion dans les textes d'enfants. Etude du développement des processus anaphoriques. Laussane-París: Delachaux \& Niestlé.

De Weck, G., \& Schneuwly, B. (1994). Anaphoric procedures in four text types written by children. Discourse Processes, 17(3) 465-477.

Decool-Mercier, N., \& Ali Akinci, M. (2010). Le foncionnement des anaphors dans les texts oraux et écrits en français d'enfants bilingues et monolingues. En F. Neveu, V. D.

Muni Toke, \& S. Prevost (Eds.), Actes Congrès Mondial de Linguistique Française (pp. 1513-1526). Paris: Institut de Linguistique Française.

Dolz, J., Noverraz, M., \& Schneuwly, B.(2001). S'exprimer en francais. Séquences didactiques pour l'oral et pour l'écrit, Vol 1 (5 séquences didactiques 1e-2e). Bruxelles: De Boeck.
Hernández Pina, M. (1985). Teorías Psicosociolingüísticas y su aplicación a la adquisición. Madrid: Siglo $\mathrm{XXI}$.

Hickmann, M. K., \& Roland, F. (1995). Cohesive anaphoric relations in French children's narratives as a fuction of mutual knowledge. First Language, 15, 277-300.

Jisa, H. (2000). Increasing cohesion in narratives: a developmental study of maintaining and reintroducing subjects in French . Linguistics, 38(3)591-620.

Kail, M., \& Sánchez y López, I. (1997). Referent introductions in Spanish narratives as a function of contextual constraints: a crosslinguistic perspective. First Language , (17),103-130.

Karmiloff-Smith, A. (1981). The gramatical marking of thematic structure in the development. En W. Deutsch (Ed.), The Child's Construction of Language (pp. 121-147). New York: Academic Press.

Pasquier, A., \& Dolz, J. (1990). Pratiques de textes informatifs: L'article encyclopédique et le texte injonctif. Education et Recherche , 12, 148-165.

Reilly, J., Zamora, A., \& Mc Givern, R. (2005). Acquiring perspective in Englush: the development of stance. Journal of Prgamatics , 37(2), 185-208.

Schneider, P., \& Dubé, R. V. (1997). Effect of pictorial versus oral story presentation on children's use of referring expressions in retell. First Language, 5(3), 283-302.

Schneuwly, B. (1988). Le Langage Écrit chez l'Enfant: La production des textes informatifs et argumentatifs. Paris: Delachaux \& Niestlé.

Shapiro, L., \& Hudson, J.(1997). Coherence and Cohesion in children stories. En J. Costermans, \& M. Fayol (Eds.), Processing interclausal relationships. Mahwah (pp. 23-48). NJ: Lawrence Erlbaum Associates.

Stotsky, S. (1983). Types of lexical cohesion in expository Writing: Implications for developing the vocabulary of academic discourse. College Composition and Communication, 34(4), 430-446.

THE AUTHORS

VERÓNICA SÁNCHEZ ABCHI is Ph.D. in Applied Linguistic (University of Córdoba, Argentina). She works as a post doc assistant at the University of Geneva (Switzerland) and at the Institut de documentation et recherche pédagogique (Neuchâtel, Switzerland). Her research interests concentrate on the writing learning and teaching process and language acquisition. She has published didactic materials and scientific articles on this topic. 
Anaphoric resources in expository texts produced by children

MARÍA DOLORES PLANA is Ph.D. in Applied Linguistic (University of Córdoba, Argentina). She works at the National Council of Scientific and Technical Research (CONICET) and she is actually working on her post doc project on children's text comprehension and working memory. She teaches also at Initial Teacher Education. She has published didactic material and scientific articles on children's narratives.

MARIA ELENA BENÍTEZ is Ph.D. in Psychology (National University of La Plata, Argentina). She has worked as a Doctoral Fellow of the National Council of Scientific and Technical Research (CONICET) and is currently working on a postdoctoral project referred to capacity of working memory and its relationship with phonological awareness skills, phonological processing and reading and writing of words in young adults with different levels of literacy. She has published scientific articles and didactic materials on linguistic and cognitive profiles of young people and adults with low literacy. 